\title{
Sensitising Breast Cancer Cells to Chemotherapy by Down Regulation of Lifeguard
}

Anna-Lena Gratzke, Kerstin Reimers, Peter M Vogt and Vesna Bucan*

Department of Plastic, Hand and Reconstructive Surgery, Medical School Hannover, Podbielskistraße 380, D-30659 Hannover, Germany

\begin{abstract}
Introduction: Lifeguard (LFG) is an anti-apoptotic protein that inhibits programmed cell death mediated by Fas in tumour cells. The exact mechanism of action and the molecular function from LFG in the carcinogenesis of human breast cells is not clear. But the expression of LFG mRNA correlates with LEF-1 transcription factor activity.
\end{abstract}

Methods: In the present study, chemotherapeutic-induced apoptotic effects were studied using MCF-7 cells as an in vitro test model. Molecular (Western blot and RT-PCR) techniques were used to investigate LFG expression. To investigate the breast cancer cell proliferation in presence of siRNA-LFG we performed fluorescent cell viability assays.

Results: The results indicated that, a decrease of LFG expression using siRNA correlates with an increased sensitivity to Trastzumab and Erlotinib. Moreover, cell cycle analysis of LEF-1 siRNA-transfected human breast cancer cells revealed a significant arrest in $G_{2}$ phase.

Conclusion: Taken together, our results indicate a pivotal role of LFG in the regulation of apoptosis in MCF-7 breast cancer cells.

Keywords: LFG; LEF-1; Chemoresistance; Apoptosis; Breast cancer

\section{Introduction}

Breast cancer as one of the most frequent diagnosed cancers at all, is the leading cause of cancer death among women worldwide and hence demands new effective therapeutic prospects [1]. Numerous studies characterized the role of the PI3-K/Akt signalling pathway as a pivotal one in cancer progression since various up regulated pathway components have been observed in cancer cells and most notably since inhibition of the Akt signal cascade has been described as resulting in apoptosis, suppression of cell survival and thus inhibition of tumour genesis [2-9].

Human epidermal growth factor receptor (HER2/neu), a member of the epidermal growth factor receptor family (EGFR) and responsible for increased levels of active Akt, is a potent target for anticancer management [10-13]. Pharmacological applications of anti HER2 monoclonal antibodies like Trastzumab (Herceptin) or EGFR inhibitors like Erlotinib (Tarceva) have been in clinical use already and afford proved inhibition of cell proliferation as well as downregulation of PI3K/Akt pathway activity $[10,14,15]$.

While recent studies presented a large number of patients who no longer respond to chemotherapy like Erlotinib and revealed a correlation to the deregulated PI3K-PTEN-Akt signal cascade [15,31], research on new medical options to overcome these resistance seems to be essential.

The anti-apoptotic protein Lifeguard (LFG), responsible for inhibition of FasL-mediated programmed cell death [16,17], was previously analysed as structurally and functionally associated to the BI- 1 and Bcl-2 family $[18,19]$, but recently to the so called LFG gene family [20]. Several studies showed that a decreased sensitivity to FasL-induced apoptosis is based on a high LFG mRNA and protein expression rate, which was notably discovered in breast cancer cell lines. LFG downregulation therefore implicates an attractive therapeutic chance for anticancer therapy via antisense oligonucleotides or siRNA
[21-23]. While the exact molecular mechanism of LFG regulation has not yet been fully understood, it is hypothesized as mediated by the PI3-K/Akt/LEF-1 signalling pathway because PI3-K/Akt inhibition in MCF-7 and MDA-MB-231 breast cancer cells leads to increased rates of apoptosis and reduced amounts of LFG mRNA and Protein [23,24]. The transcription factor LEF-1 plays a crucial part in the regulation of cellular development and differentiation $[25,26]$ in breast cancer $[27,28]$.

Using MCF-7 breast cancer cells, we investigated the impact of LFG and LEF-1 suppression on cell proliferation, viability and apoptosis.

\section{Materials and Methods}

\section{Cell lines}

Human breast carcinoma cell lines MCF-7 (ATCC, Manassas, USA) were used in this study and grown in Dulbecco's modified Eagle's medium (DMEM, PAA, Cölbe, Germany) supplemented with $10 \%$ FCS (Biochrom, Berlin, Germany) and $50 \mathrm{mg} / \mathrm{ml}$ penicillinstreptomycin. Cultures were maintained at $37^{\circ} \mathrm{C}$ with $5 \%$ carbon dioxide in a humidified atmosphere. The medium was changed every 2 to 3 days, and cells were subcultured by treatment with $0.25 \%$ Trypsin/0.53 mM ethylenediaminetetraaceticacid (EDTA) (Biochrom, Berlin, Germany) solution.

*Corresponding author: Vesna Bucan, Klinik für Plastische, Hand- und Wiederherstellungschirurgie, Medizinische Hochschule Hannover, Carl-Neubergstr. 1, 30625 Hannover, Germany, Tel: 0511 532-0; E-mail: Vesna@mh-hanover.de

Received July 28, 2014; Accepted September 24, 2014; Published September 27, 2014

Citation: Gratzke AL, Reimers K, Vogt PM, Bucan V (2014) Sensitising Breas Cancer Cells to Chemotherapy by Down Regulation of Lifeguard. J Cancer Sci Ther 6: 411-416. doi:10.4172/1948-5956.1000301

Copyright: (c) 2014 Gratzke AL, et al. This is an open-access article distributed under the terms of the Creative Commons Attribution License, which permits unrestricted use, distribution, and reproduction in any medium, provided the original author and source are credited. 


\section{Real-time polymerase chain reaction}

Total RNA was isolated from cultured cells using the NucleoSpin RNAII Kit (MN Macherey-Nagel, Duren, Germany) according to the manufacturer's protocol. RNA concentration was measured by photometry at NanoDrop (PeqLab, Erlangen, Germany). The quality of total RNA was verified by the integrity of $18 \mathrm{~S} / 28 \mathrm{~S}$ ribosomal RNA in $1 \%$ ethidium bromide-stained agarose gels. Reverse transcription (RT) was performed with $1 \mu \mathrm{g}$ total RNA using iScript ${ }^{\mathrm{TM}} \mathrm{cDNA}$ Kit (BioRad Laboratories, Hercules, CA). Real-time polymerase chain reaction (Q-PCR) reaction was carried out in $20 \mu \mathrm{l}$ samples with 5ng cDNA and 10 pmol of each forward and reverse primer and 2x SYBR green SensiMix DNA Kit (Quantace, London, U.K.). Relative gene expression was determined by the fluorescence intensity ratio of the target gene to B2Microglobulin. The primers used in the real-time PCR reaction were designed based on information from the human genomic data base. The following primer sequences were used:

human LFG: forward: 5 '-gactcatcctggccatcctcctac-3’

reverse: $5^{`}$-ggcgtcggttacccatcagc-3`;

human. LEF-1: forward: 5 'agagaaaggagcag-3', reverse: 5 ' -attgtctcttgcag-3',

ß2-Microglobulin: forward: 5 '-atgagtatgcctgccgtgtga-3 reverse: $5^{\prime}$-ggcatcttcaaacctccatg-3’.

The initial denaturation step at $94^{\circ} \mathrm{C}$ for $4 \mathrm{~min}$. was followed by 40 cycles of denaturation for $30 \mathrm{~s}$, annealing at $65^{\circ} \mathrm{C}$ for $30 \mathrm{~s}$, extension at $72^{\circ} \mathrm{C}$ for $1 \mathrm{~min}$., and final extension step at $72^{\circ} \mathrm{C}$ for $10 \mathrm{~min}$. All experiments were carried out in triplicate and repeated at least at three independent times. The specificity of the Q-PCR products was proven by the appropriate melting curves (specific melting temperature).

\section{Western blot analysis}

For Western blot analysis, cells were lysed in RIPA buffer containing $0.3 \mathrm{M} \mathrm{NaCl}, 1 \%$ sodium desoxycholate, $0.1 \%$ sodium dodecyl sulfate (SDS), 1\% Triton-X-100, $20 \mathrm{mM}$ Tris-HCL (pH 8), 1 $\mathrm{mM}$ EDTA, and $1 \mathrm{mM}$ phenylmethyl sulfonyl fluoride. $25 \mu \mathrm{g}$ of protein were fractionated by $15 \%$ SDS-PAGE and transferred to polyvinylidene fluoride (PVDF) membranes (Millipore Corporation, Bedford, USA), then blocked in Odyssey buffer for $1 \mathrm{hr}$. Protein expression levels were determined by immunoblotting with the following antibodies: anti-hLFG (1:200 dilution) (IMGENEX, San Diego, CA), monoclonal anti-LEF-1 (at 1:500) purchased from Abcam, Cambrige, UK, and antigoat- $\beta$-Actin (at 1:1000) (Abcam, Cambrige, UK), at $4^{\circ} \mathrm{C}$ overnight. For quantification of protein expression levels, Odyssey 680/800 nm secondary conjugates were used and PVDF membranes were analysed using the Odyssay Infra-Red Imaging System and software (Li-Cor BioSciences, Lincoln, Nebraska, USA).

\section{Small interfering RNA}

In this study, we transfected MCF-7 cells with siRNA LFG-5 'gggcaaagaaacattctatgt-3', control siRNA LFG5 'ggaatctcattcgatgcatac-3' (designed by SuperArray Bioscience Corporation, USA) and with siRNA LEF-1-5 ' guugcugaguguacucuaa-3', control siRNA LEF-1-5 ' uuagaguacacucagcaa-3' (designed by Ambion, USA). The cells were seeded at $1 \times 10^{4}$ cells and incubated at $37^{\circ} \mathrm{C}, 5 \%$ $\mathrm{CO}_{2}$ in humidified atmosphere for $48 \mathrm{hrs}$ before being analysed.

\section{Caspase assay}

Activation of caspase-3/7 was determined using the Apo-One
Homogeneous Caspase-3/7 Assay (Promega, Madison, WI) following the protocol provided by the manufacturer. Briefly, $1 \times 10^{4} \mathrm{MCF}-7$ breast cancer cells were seeded per well of a 96 well plate and transfected with siRNA LFG and control siRNA, for $48 \mathrm{hrs}$. After $48 \mathrm{hrs}$ cells were incubated with $0.25 \mathrm{mg} / \mathrm{ml}, 0.5 \mathrm{mg} / \mathrm{ml}$ or $1 \mathrm{mg} / \mathrm{ml}$ of Trastzumab (Hercetin', Roche) or Erlotinib (Tarceva, Roche) for $2 \mathrm{hrs}$ and $4 \mathrm{hrs}$, respectively. After treatment, cells were mixed with the same volume of Apo-One Homogeneous Caspase-3/7 reagent and incubated at room temperature for $2 \mathrm{hrs}$. Caspase-3/7 activation was estimated from sample fluorescence at the excitation wavelength of $492 \mathrm{~nm}$ and the emission wavelength of $521 \mathrm{~nm}$ using a fluorescence plate reader Tecan GENios (TECAN, Männedorf, Switzerland).

\section{Cell viability assay}

Metabolic activity was determined by Cell Titer Blue cell viability assays (Promega, Madison, USA). Briefly, $1 \times 10^{4}$ cells from MCF-7 breast cancer cells were seeded, $1 \times 10^{5}$ cells per well of a 96 well plate and transfected with siRNA LEF-1 and control siRNA, for $48 \mathrm{hrs}$ (HiPerFect Transfection Reagent; Fa. Qiagen). Relative numbers of viable cells were measured in comparison to the untreated control and the solvent control according to the manufacturer's instructions at $560_{\mathrm{Ex}} / 590_{\mathrm{Em}} \mathrm{nm}$ in a fluorescence plate reader TecanGENios (TECAN, Männedorf, Switzerland).

\section{Cell cycle analysis by flow cytometry}

Viability analysis of the cells was performed in a Vi-CELL Series Cell Viability Analyzer (Beckman Coulter GmbH, Krefeld, Germany). For distinct cell cycle phase distribution, about $10^{6}$ breast cancer cells were analysed. Thus, the cells were harvested and fixed in $70 \%(\mathrm{v} / \mathrm{v})$ ice-cold ethanol and kept at $4^{\circ} \mathrm{C}$ for $24 \mathrm{~h}$. Thereafter, the fixed cells were stained with CyStain DNA 2 step kit (Partec $\mathrm{GmbH}$, Münster, Germany) and filtered through a $50 \mu \mathrm{m}$ filter. These samples were then analyzed in Galaxy flow cytometer (Dako, Hamburg, Germany) using FloMax analysis software (Partec) and the MultiCycle cell cycle software (Phoenix Flow Systems Inc., San Diego, CA, USA).

\section{Results}

\section{Downregulation of LFG and LEF-1 expression by siRNA transfection}

In order to demonstrate the impact of LFG and LEF-1 protein in breast cancer, MCF-7 cells were transfected as described in experimental procedures, with designed LFG specific siRNA and with designed LEF-1 specific siRNA, respectively. After $48 \mathrm{~h}$, quantitative RT-PCR and Western blot analysis were performed to determine successful gene silencing. While the transfected cells exhibited decreased levels of LEF-1 and LFG mRNA respectively (Figures 1A and B), we also found, as expected, reduced amounts of LEF-1 and LFG protein (Figure 1C) compared to the si-Control and untreated Control cells.To examine the effect of LFG and LEF-1 downregulation on the apoptosis and viability in breast carcinoma cells, we transfected MCF-7 cells with siRNA LFG or siRNA LEF-1as before. Appropriate vitality measurements demonstrated reduced cell viability in LEF-1 siRNA transfectants as compared to control siRNA and untreated cells after $48 \mathrm{~h}$ (Figure 2A). Moreover, proliferative effects of LEF-1 downmodulation were assayed by cell cycle analysis. Following transfection of MCF-7 breast cancer cells with LEF-1 siRNA for $48 \mathrm{~h}$, cell cycle phases were determined by flow cytometry analysis. Thus, LEF-1 siRNA transfection of MCF-7 demonstrated a significantly reduced amount of $S$ phase cells and a marked accumulation of cells in G2 phase (Figure 3). Quantitative analysis of the cell cycle phases revealed a similar 
A.

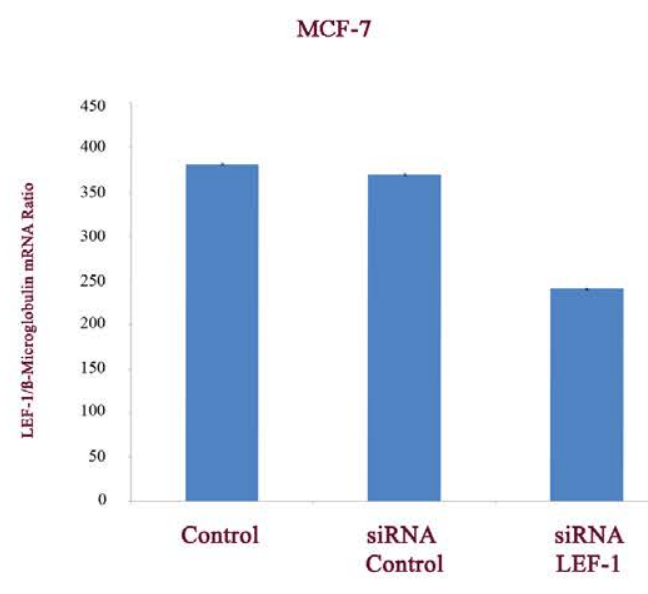

B.

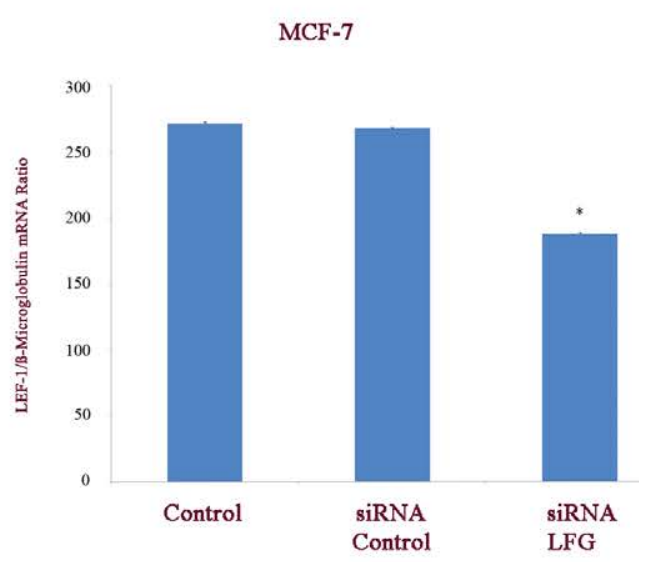

C.

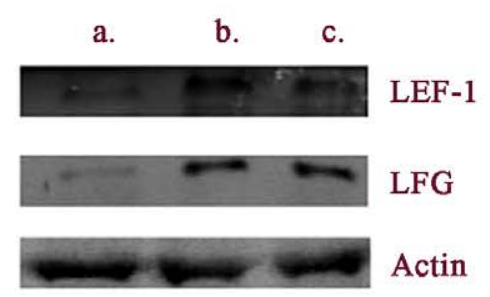

Figure 1: Downregulation of LFG and LEF-1 gene expression. A. The human breast carcinoma cell line MCF-7 were transfected with siRNA LEF-1 for $48 \mathrm{~h}$ and analysed for relative LEF-1 mRNA ratio compared to the control using RT-PCR, and B. MCF-7 cells were transfected with siRNA LFG for 48 $\mathrm{h}$ and analysed for relative LFG mRNA ratio compared to the control using $\mathrm{RT}-\mathrm{PCR}$. The data are the means \pm SD of triplicate determinations which were repeated in three separate experiments. ${ }^{*} p<0.05$ vs. control. C. MCF-7 cells were transfected with siRNA (a: siRNA LEF-1 or siRNA LFG; b: siRNAcontrol; c: nontransfected cells ) for $48 \mathrm{~h}$ and then cell lysates were subjected to Western blotting to detect the quantity of expressed LEF-1 (LFG). Actin was used for normalization.
$\Lambda$.

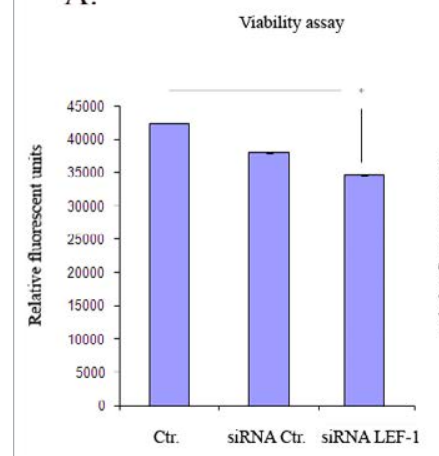

B.

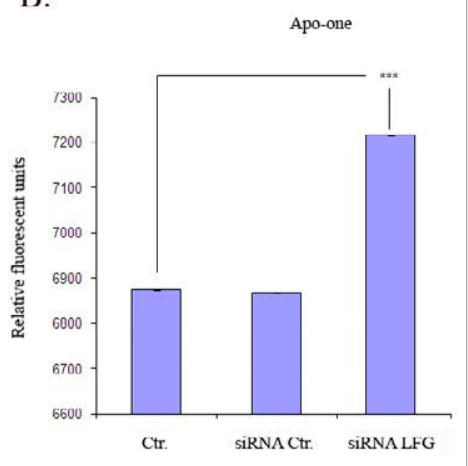

Figure 2: $\quad$ of LFG and LEF-1 on proliferation and apoptosis. A MCF-7 cells were transfected with siLEF-1 for $48 \mathrm{~h}$ and the cell viability was determined using the cell viability assay. B. MCF-7 cells were transfected with siLFG, for $48 \mathrm{~h}$ and analysed for activated levels of caspase 3 using the Caspase Assay. Data are the means \pm SD of triplicate determinations which were repeated in three separate experiments. ${ }^{*} p<0.05,{ }^{* * *} p<0.001$ vs. the control.
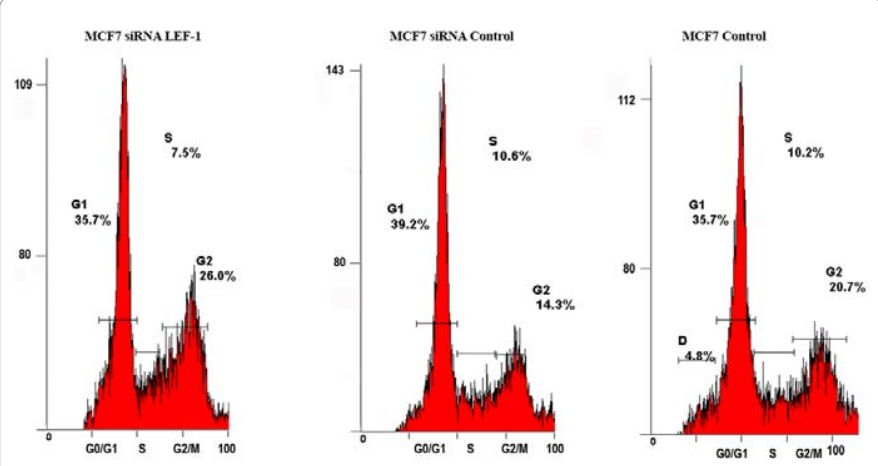

Figure 3: Effects of LEF-1 gene suppression on the cell cycle of MCF-7 breast cancer cells. MCF-7 cells were transfected with LEF-1 specific siRNA for $48 \mathrm{~h}$ and then analysed for cell cycle phase distribution by flow cytometry, compared to the nontransfected cells and the control siRNA.

cell cycle distribution in MCF-7 control cells and the population's transfected with a control siRNA reaching about about $10.2 \%$ to $10.6 \%$ of cells in S phase and about $20.7 \%$ to $14.3 \%$ of cells in G2/M phase, respectively. In contrast, down-modulation of LEF-1 after $48 \mathrm{~h}$ of LEF1 siRNA transduction was associated with a significant decline of the $\mathrm{S}$ phase to about $7.5 \%$ respectively (Figure 3 ). Conversely, a significant accumulation of cells in G2/M phase to about $26 \%$ detectable in $48 \mathrm{~h}$ LEF-1 siRNA transfectants (Figure 4B).

Furthermore, we found significant increased levels of activated caspase-3/7 in MCF-7 cells with downregulated expression of LFG compared to control siRNA and untreated cells after $48 \mathrm{~h}$ (Figure 2B). Consequently we demonstrated that downregulation of LFG correlates with an increased sensitivity to chemotherapeutical treatment measured by increased rates of apoptosis.

\section{Sensitisation of MCF-7 cells against chemotherapeutical treatment in consequence of LFG gene suppression}

To corroborate our hypothesis, that downregulated expression of LFG has direct effects on the chemotherapeutic given of breast cancer cells, we transfected MCF-7 cells with LFG specific siRNA and treated them with $0.25 \mathrm{mg} / \mathrm{ml} ; 0.5 \mathrm{mg} / \mathrm{ml}$ or $1 \mathrm{mg} / \mathrm{ml}$ of the cytostatic drugs "Erlotinib" or "Trastzumab" respectively. Following $2 \mathrm{~h}$ and $4 \mathrm{~h}$ of 
A.

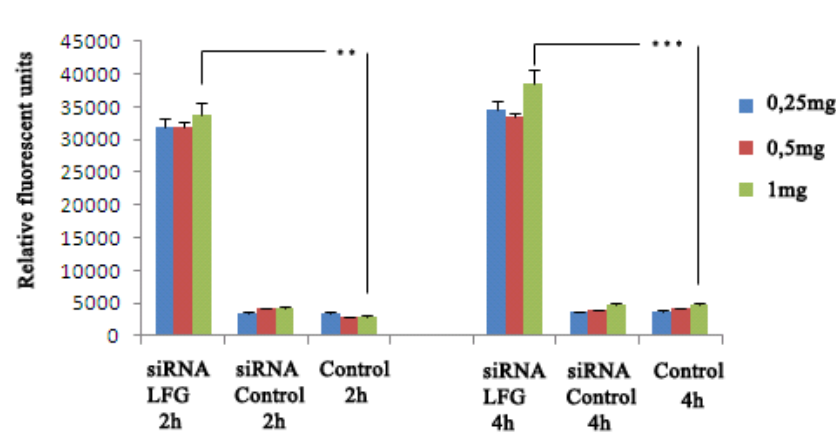

B.

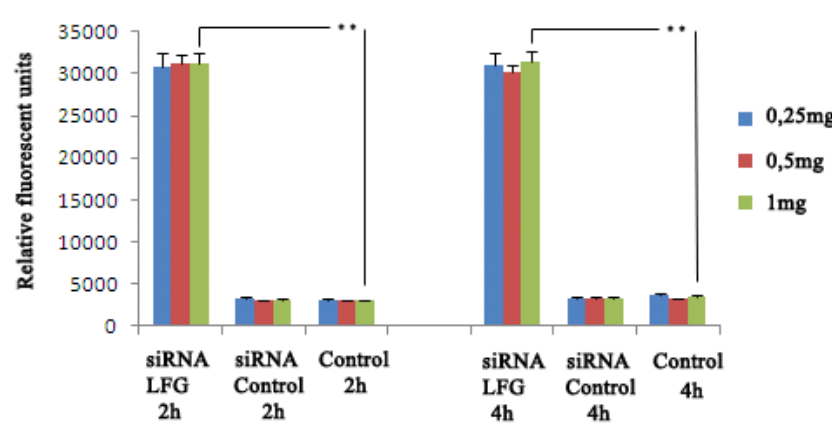

Figure 4: The impact of LFG suppression on the apoptosis of MCF-7 cells after chemotherapeutical treatment with "Erlotinib" and "Trastzumab". A. MCF-7 breast cancer cell was transfected with siRNA LFG. Following transfection the cells were treated with the chemotherapeutic agent "Erlotinib" using different times $(2 \mathrm{~h} ; 4 \mathrm{~h})$ and concentrations $(0,25 \mathrm{mg} / \mathrm{ml} ; 0,5 \mathrm{mg} / \mathrm{ml} ; 1 \mathrm{mg} /$ $\mathrm{ml})$. These stimulated cells were analysed for activated level of caspase 3 using the Apo-One assay and compared to the nontransfected cells and the control. B. MCF-7 breast cancer cell were transfected with siRNA LFG. Following transfection the cells were treated with the chemotherapeutic agent "Trastzumab" using different times $(2 \mathrm{~h} ; 4 \mathrm{~h})$ and concentrations $(0,25 \mathrm{mg} / \mathrm{ml}$; $0,5 \mathrm{mg} / \mathrm{ml} ; 1 \mathrm{mg} / \mathrm{ml}$ ). These stimulated cells were analysed for activated level of caspase 3 using the Caspase Assay and compared to the nontransfected cells and the control. Data are the means \pm SD of duplicate determinations which were repeated in two separate experiments. ${ }^{*} p<0.05,{ }^{* *} p<0.01,{ }^{* * *} p<0.001$ vs. the control.

incubation we detected a significantly increased levels of caspase 3/7 in the LFG siRNA transfectants compared the si-Control and nontransfected cells (Figure 4). The activation of apoptosis demonstrated the potential of LFG gene silencing for sensitisation of MCF-7 breast cancer cells towards chemotherapeutical treatment.

\section{Discussion}

In addition to the fact that breast cancer is still the leading cause of cancer death in women worldwide [1], numerous studies have described the occurrence of resistances to conventional chemotherapy in cancer cells [14,29-33] and therefore underline the importance of understanding expression, regulation and function of signalling pathways. Dysfunction of this cell death system is contributed to several deregulations of antiapoptotic proteins like Bcl-2, Bcl-xl or BI-1 $[19,39,40]$.
Cognition of the oncogenic potential from HER2 that is based on aberrant overexpression correlating with tumorigenesis and poor clinical outcome in breast cancer reveals the role of anti HER2 therapy [10-12]. Trastzumab is a humanized monoclonal antibody, which binds directly on the extracellular domain of the HER2 to initiate several mechanisms include the PI3K/Akt pathway and the MAPK pathway whereas Erlotinib, a small molecular EGFR inhibitor, targets the ATP-binding site of EGFR. Thereby, activity of the tyrosin kinase gets depressed and results in promoting inhibition of proliferation and induction of apoptosis in cancer cells [15,37,38]. Both drugs interfere with the crucial PI3K-PTEN-Akt signal cascade, which is moreover determined to be deregulated in breast cancer cell and hence responsible for drug resistance $[10,14,29-31,39,40]$. LFG an antiapoptotic protein with potential involvement in cancer progression and previously well described [16-21], is the target gene of the AKT/LEF-1 pathway are for this studies one potential regulator of apoptosis in tumour cells $[23,24]$.

After treatment of MCF-7 breast cancer cells with LFG-specific siRNA, successful downregulation of LFG expression was proved by analysing the amount of mRNA and protein (Figures 1A and C), we demonstrated that this kind of gene silencing affects a significant raised level of activated caspase-3/7, which indicates an increased rate of apoptosis (Figure 2B).

Investigating clinical possibilities given by these findings, we detected here for the first time convincing evidence that LFG gene suppression sensitizes breast cancer cells to chemotherapeutical treatment (Figure 4). Following LFG gene silencing via specific siRNA transfection in MCF-7 breast cancer cells, our data clearly revealed significantly increased levels of activated caspase-3/7 after incubation with cytostatic drugs (e.g. Erlotinib or Trastzumab), compared to the siControl and nontransfected cells. To contrast this results with the rate of apoptotis in LFG downregulated cells without chemotherapeutical treatment, we even showed a fivefold advance, which indicate the combined use of siRNA and chemotherapy as an enhanced effective strategy (Figure 2A and 4). Our findings are congruent with studies focused on other anti-apoptotic proteins like bcl-2, bcl-xl or p53 [3236], and demonstrated as well favourable prospects using siRNA to overcome chemoresistance by inhibiting protein expression.

Our results displayed a slightly more potent treatment of Erlotinib to initiate apoptotic processes in LFG downregulated MCF-7 cells as compared with Trastzumab treated ones (Figure 4). This effect possibly originated from their different mechanism of inhibition, but still needs to be further elucidated. In both experimental parts the level of activated caspase-3/7 raised up on the sevenfold already $2 \mathrm{~h}$ after treatment with lowest dose of $0.25 \mathrm{mg} / \mathrm{ml}$, whereas an increasing concentrations on the double or fourfold no increased apoptosis proportional of the used chemotherapeutic concentration shows. This considerable suggest the high potential of sensitising.

LEF-1, member of the TCF/ LEF family and hence a regulatory participant in cell maturation and development $[25,26]$, was identified as a LFG controlling transcription factor [24] and is therefore an important part of our studies. In the present study we demonstrated the critical role of LEF-1 on viability and proliferation in MCF-7 breast cancer cell. siRNA mediated downregulation of LEF-1 mRNA and protein (Figure 1A and $\mathrm{C}$ ) led to an obvious reduction of cell viability in general (Figure 2A) and to an inhibition of proliferation caused by an increased accumulation of cells in the G2 phase of cell cycle (Figure $3)$. Based on previous reports, which have described the upregulation or aberrant activation of LEF-1 during cancer progression [28,41,42], 
our findings indicated that LEF-1 may be suited as a new target in anticancer management.

In conclusion the present study corroborates the essential role of LFG and its regulatory transcription factor LEF-1 as well as its regulatory mechanisms. Moreover demonstrates here for the first time sensitisation of breast cancer cells to chemotherapeutics, caused by LFG gene suppression. In prospective, our results have to be tested in context with other resistant types of cancer plus different chemotherapeutics and finally proved in preclinical in vivo experiments.

\section{Acknowledgement}

The work was funded by the Niedersächsische Krebsgesellschaft. The authors are grateful to Andrea Lazaridis for excellent technical assistance.

The authors declare that they have no competing interests.

\section{References}

1. Ferlay J, Shin HR, Bray F, Forman D, Mathers C, et al. (2010) Estimates of worldwide burden of cancer in 2008: GLOBOCAN 2008. Int J Cancer 127: 2893-2917.

2. Chen $Y$, Wang BC, Xiao $Y$ (2012) PI3K: a potential therapeutic target for cancer. J Cell Physiol 227: 2818-2821.

3. Carson JD, Van Aller G, Lehr R, Sinnamon RH, Kirkpatrick RB, et al. (2008) Effects of oncogenic $\mathrm{p} 110$ alpha subunit mutations on the lipid kinase activity of phosphoinositide 3-kinase. Biochem J 409: 519-524.

4. Pang H, Flinn R, Patsialou A, Wyckoff J, Roussos ET, et al. (2009) Differential enhancement of breast cancer cell motility and metastasis by helical and kinase domain mutations of class IA phosphoinositide 3-kinase. Cancer Res 69: 8868-8876

5. Cheng JQ, Lindsley CW, Cheng GZ, Yang H, Nicosia SV (2005) The Akt/PKB pathway: molecular target for cancer drug discovery. Oncogene 24: 7482-7492.

6. Altomare DA, Testa JR (2005) Perturbations of the AKT signaling pathway in human cancer. Oncogene 24: 7455-7464.

7. Hu L, Zaloudek C, Mills GB, Gray J, Jaffe RB (2000) In vivo and in vitro ovarian carcinoma growth inhibition by a phosphatidylinositol 3-kinase inhibitor (LY294002). Clin Cancer Res 6: 880-886.

8. Panka DJ, Mano T, Suhara T, Walsh K, Mier JW (2001) Phosphatidylinositol 3-kinase/Akt activity regulates C-FLIP expression in tumor cells. J Biol Chem 276: 6893-6896.

9. Salatino M, Schillaci R, Proietti CJ, Carnevale R, Frahm I, et al. (2004) Inhibition of in vivo breast cancer growth by antisense oligodeoxynucleotides to type I insulin-like growth factor receptor mRNA involved inactivation of ErbBs, PI-3K/ Akt and p42/p44 MAPK signalling pathway but not modulation of progesterone receptor activity. Oncogene 23: 5161-5174.

10. Longva KE, Pedersen NM, Haslekås C, Stang E, Madshus IH (2005) Herceptininduced inhibition of ErbB2 signaling involves reduced phosphorylation of Akt but not endocytic down-regulation of ErbB2. Int J Cancer 116: 359-367.

11. Holbro T, Civenni G, Hynes NE (2003) The ErbB receptors and their role in cancer progression. Exp Cell Res 284: 99-110.

12. Olayioye MA, Neve RM, Lane HA, Hynes NE (2000) The ErbB signaling network: receptor heterodimerization in development and cancer. EMBO J 19: 3159-3167.

13. Schlessinger $\mathrm{J}$ (2004) Common and distinct elements in cellular signaling via EGF and FGF receptors. Science 306: 1506-1507.

14. Hermes M, Schormann W, Brulport M, Uhlemann K, Lupatsch F, et al. (2008) Trastuzumab therapy vs tetracycline controlled ERBB2 downregulation: influence on tumour development in an ERBB2-dependent mouse tumour model. Br J Cancer 98: 1525-1532.

15. Guix M, Granja Nde M, Meszoely I, Adkins TB, Wieman BM, et al. (2008) Short preoperative treatment with erlotinib inhibits tumor cell proliferation in hormone receptor-positive breast cancers. J Clin Oncol 26: 897-906.

16. Somia NV, Schmitt MJ, Vetter DE, Van Antwerp D, Heinemann SF, et al. (1999)
LFG: an anti-apoptotic gene that provides protection from Fas-mediated cell death. Proc Natl Acad Sci U S A 96: 12667-12672.

17. Fernández M, Segura MF, Solé C, Colino A, Comella JX, et al. (2007) Lifeguard/ neuronal membrane protein 35 regulates Fas ligand-mediated apoptosis in neurons via microdomain recruitment. J Neurochem 103: 190-203.

18. Reimers K, Choi CY, Mau-Thek E, Vogt PM (2006) Sequence analysis shows that Lifeguard belongs to a new evolutionarily conserved cytoprotective family. Int J Mol Med 18: 729-734.

19. Reimers K, Choi CY, Bucan V, Vogt PM (2008) The Bax Inhibitor-1 (BI-1) family in apoptosis and tumorigenesis. Curr Mol Med 8: 148-156.

20. Hu L, Smith TF, Goldberger G (2009) LFG: a candidate apoptosis regulatory gene family. Apoptosis 14: 1255-1265.

21. Bucan V, Reimers K, Choi CY, Eddy MT, Vogt PM (2010) The anti-apoptotic protein lifeguard is expressed in breast cancer cells and tissues. Cell Mol Biol Lett 15: 296-310.

22. Bucan V, Choi CY, Lazaridis A, Vogt PM, Reimers K (2011) Silencing of antiapoptotic transmembrane protein lifeguard sensitizes solid tumor cell lines MCF-7 and SW872 to perifosine-induced cell death activation. Oncol Lett 2: 419-422.

23. Beier CP, Wischhusen J, Gleichmann M, Gerhardt E, Pekanovic A, et al. (2005) FasL (CD95L/APO-1L) resistance of neurons mediated by phosphatidylinositol 3-kinase-Akt/protein kinase B-dependent expression of lifeguard/neuronal membrane protein 35. J Neurosci 25: 6765-6774.

24. Bucan V, Adili MY, Choi CY, Eddy MT, Vogt PM, et al. (2010) Transactivation of lifeguard (LFG) by Akt-/LEF-1 pathway in MCF-7 and MDA-MB 231 human breast cancer cells. Apoptosis 15: 814-821.

25. Travis A, Amsterdam A, Belanger C, Grosschedl R (1991) LEF-, a gene encoding a lymphoid-specific protein with an HMG domain, regulates T-cell receptor alpha enhancer function [corrected]. Genes Dev 5: 880-894.

26. Eastman Q, Grosschedl R (1999) Regulation of LEF-1/TCF transcription factors by Wnt and other signals. Curr Opin Cell Biol 11: 233-240.

27. Shulewitz M, Soloviev I, Wu T, Koeppen H, Polakis P, et al. (2006) Repressor roles for TCF-4 and Sfrp1 in Wnt signaling in breast cancer. Oncogene 25: 4361-4369.

28. Nguyen A, Rosner A, Milovanovic T, Hope C, Planutis K, et al. (2005) Wnt pathway component LEF1 mediates tumor cell invasion and is expressed in human and murine breast cancers lacking ErbB2 (her-2/neu) overexpression. Int J Oncol 27: 949-956.

29. Fiszman GL, Jasnis MA (2011) Molecular Mechanisms of Trastuzumab Resistance in HER2 Overexpressing Breast Cancer. Int J Breast Cancer 2011: 352182.

30. Berns K, Horlings HM, Hennessy BT, Madiredjo M, Hijmans EM, et al. (2007) A functional genetic approach identifies the PI3K pathway as a major determinant of trastuzumab resistance in breast cancer. Cancer Cell 12: 395-402.

31. Bartholomeusz C, Yamasaki F, Saso H, Kurisu K, Hortobagyi GN, et al (2011) Gemcitabine Overcomes Erlotinib Resistance in EGFR-Overexpressing Cancer Cells through Downregulation of Akt. J Cancer 2: 435-442.

32. Yamanaka K, Rocchi P, Miyake H, Fazli L, So A, et al. (2006) Induction of apoptosis and enhancement of chemosensitivity in human prostate cancer LNCaP cells using bispectific antisense oligonucleotide targeting $\mathrm{Bcl}-2$ and Bcl-xL gened. BJU Int 97: 1300-1308.

33. Giménez-Bonafé P, Tortosa A, Pérez-Tomás R (2009) Overcoming drug resistance by enhancing apoptosis of tumor cells. Curr Cancer Drug Targets 9: 320-340.

34. Duggan BJ, Maxwell P, Kelly JD, Canning P, Anderson NH, et al. (2001) The effect of antisense $\mathrm{Bcl}-2$ oligonucleotides on $\mathrm{Bcl}-2$ protein expression and apoptosis in human bladder transitional cell carcinoma. J Urol 166: 1098-1105.

35. Zangemeister-Wittke U, Leech SH, Olie RA, Simões-Wüst AP, Gautschi O, et al. (2000) A novel bispecific antisense oligonucleotide inhibiting both blc-2 and bcl-xL expression efficiently induces apoptosis in tumor cells. Clin Cancer Res 6: 2547-2555

36. Wacheck V, Zangemeister-Wittke $U$ (2006) Antisense molecules for targeted cancer therapy. Crit Rev Oncol Hematol 59: 65-73.

37. Zangemeister-Wittke U (2005) Antibodies for targeted cancer therapy -technical aspects and clinical perspectives. Pathobiology 72: 279-286. 
Citation: Gratzke AL, Reimers K, Vogt PM, Bucan V (2014) Sensitising Breast Cancer Cells to Chemotherapy by Down Regulation of Lifeguard. J Cancer Sci Ther 6: 411-416. doi:10.4172/1948-5956.1000301

38. Slamon DJ, Leyland-Jones B, Shak S, Fuchs H, Paton V, et al. (2001) Use of chemotherapy plus a monoclonal antibody against HER2 for metastatic breast cancer that overexpresses HER2. N Engl J Med 344: 783-792.

39. Nagata Y, Lan KH, Zhou X, Tan M, Esteva FJ, et al. (2004) PTEN activation contributes to tumor inhibition by trastuzumab, and loss of PTEN predicts trastuzumab resistance in patients. Cancer Cell 6: 117-127.

40. García-García C, Ibrahim YH, Serra V, Calvo MT, Guzmán M, et al. (2012) Dual mTORC1/2 and HER2 blockade results in antitumor activity in preclinical models of breast cancer resistant to anti-HER2 therapy. Clin Cancer Res 18 2603-2612.

41. Simon M, Grandage VL, Linch DC, Khwaja A (2005) Constitutive activation of the Wnt/beta-catenin signalling pathway in acute myeloid leukaemia. Oncogene 24: 2410-2420.

42. Li FQ, Person RE, Takemaru K, Williams K, Meade-White K, et al. (2004) Lymphoid enhancer factor- 1 links two hereditary leukemia syndromes through core-binding factor alpha regulation of ELA2. J Biol Chem 279: 2873-2884. 